\title{
Geotechnical investigation of pavement failure; causes and inherent solutions for sustainable highway construction in Sub-Saharan Africa
}

Rudarsko-geološko-naftni zbornik

(The Mining-Geology-Petroleum Engineering Bulletin) UDC: $625: 625 \cdot 7 / .8$

DOI: 10.17794/rgn.2020.4.9

Professional paper

\author{
Omowumi Ademila'; Abel Idowu Olayinka ${ }^{2}$ \\ ${ }^{1}$ Department of Earth Sciences, Adekunle Ajasin University, P.M.B. 001, Akungba-Akoko, Nigeria, ORCID: 0000-0001-5177-1110 \\ ${ }^{2}$ Department of Geology, University of Ibadan, Ibadan, Nigeria, ORCID: 0000-0003-1834-5157
}

\begin{abstract}
Engineering geological investigation of some unstable and stable sections of the Ibadan-Iwo-Osogbo highway was undertaken to unravel the intrinsic reasons responsible for continuous pavement failure along this road. Eighty disturbed and forty undisturbed soil samples were collected at different depths from twenty test pits of six selected failed sections (FS) and two stable sections (SS). Road construction analysis was done on these soil samples using standard methods. Liquid limit (22-64\% and $32-40 \%)$, plasticity index (13-41\% and $12-18 \%)$ and percentage fines $(47-59 \%$ and $32-41 \%)$ indicated fair to poor and fair to good subgrade materials of FS and SS respectively. Medium to high plasticity and high clay content of soils of FS are indicative that the soils possess medium to high swelling potential. The activity of clay in soils of FS was approximately $0.3-1.2$ and classified as inactive to normal clay. High linear shrinkage (> 10\%), low compacted density and predominance of fines in soils of FS caused the instability. Exposure to excessive moisture led to strength reduction of the soils. Triaxial compression showed cohesion $\left(72.6-127.0 \mathrm{kN} / \mathrm{m}^{2}\right)$ and internal friction $\left(12.7^{\circ}-\right.$ $33.3^{\circ}$ ) indicating moderate to good shearing strength of the soils. A coefficient of compressibility of $0.1-0.5 \mathrm{kN} / \mathrm{m}^{2}$ indicated incompetency of the soils for road construction and the coefficient of consolidation was $0.01-0.30 \mathrm{~m}^{2} / \mathrm{year}$ The subsoil of the FS is impervious with a relatively low coefficient of permeability, indicative high saturation in the region. Thus, the pavement failure was caused by water absorbing clayey soil, poor geotechnical parameters of the soils and a poor drainage network.
\end{abstract}

\section{Keywords:}

Pavement failure; Geotechnical parameters; Road foundation; Clay activity; Ibadan-Iwo-Osogbo highway

\section{Introduction}

The role of roads in trade and transportation globally cannot be overemphasized as they serve as links between towns, states and countries. However, Sub-Saharan Africa roads are relatively unsafe due to their deplorable state with incessant losses from accidents. The occurrence of soil makes it available as a construction material in engineering works. Most engineering works are either erected on rocks for a strong foundation or on soil, which also supports the structure. Soil displays considerable variability in its characteristics and properties owing to a variety of geologic factors. The engineering properties of soil define its applicability for different uses. They facilitate the estimation of soil response to different conditions that may be applied to it as a construction material or foundation. The performance of engineering works will depend on a correct assessment and prediction of soil performance for the intended use. Most structural failures can be attributed to inadequate knowledge of the competency of substandard materials

Corresponding author: Omowumi Ademila

omowumi.ademila@aaua.edu.ng used for construction purposes. Road accidents in Nigeria has been increasing consistently due to bad roads. Thus, highway pavements and their subsoil foundation have been a general concern in a bid to bring about highway development and boost the socio-economic activities of African nations (Ademila, 2018). This is to offer an assurance of the suitability of the subsoil and highway pavement for sustainable construction. Adeyemi and Oyeyemi (2000) expressed some geotechnical properties of subgrade soils in unstable sections of the Lagos-Ibadan expressway. Poor subbase materials and poor compaction during construction account for the failure of rigid pavements in Nigeria (Olayinka et al., 2007). Unstable sections of highway in Nigeria are considered to be as a result of poor geotechnical characteristics of the subsoil that form the road structure (Ademila, 2018). Thus, documentation and proper referencing of geophysical/geotechnical data are essential for pavement design and road construction of roads (Ademila, 2017), which are vital to effectively characterize the heterogeneous subsoil properties and enhance highway development. Certain sections of roadway between IbadanIwo-Osogbo have been abandoned due to the deteriorat- 


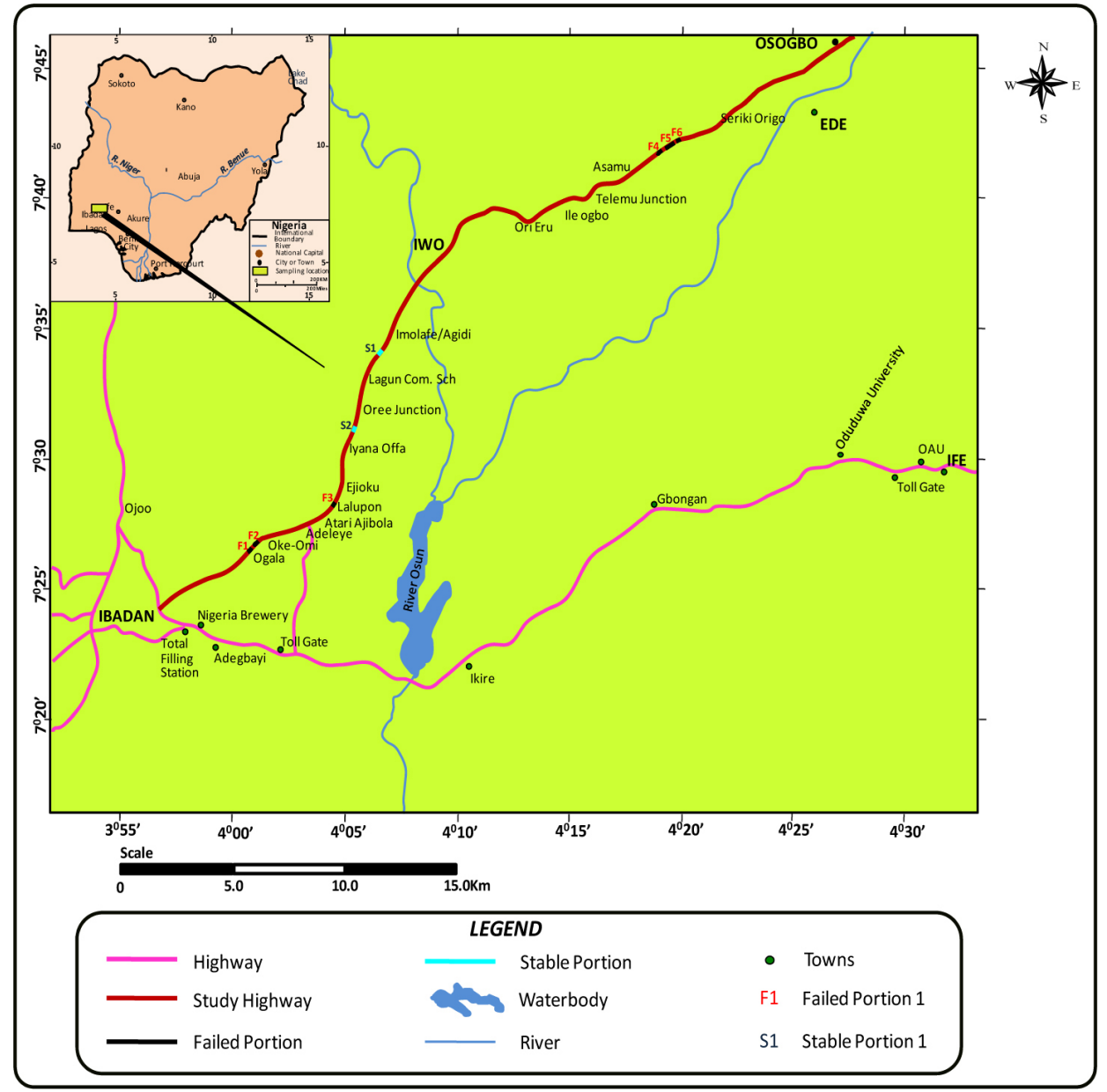

Figure 1: Location map of the study area showing the unstable and stable sections of the road.

ing state of the pavements despite several maintenance and reconsruction works carried out over the years. Engineering investigation of some unstable sections was therefore undertaken to unravel the intrinsic reasons responsible for the continuous pavement failure along this road in order to proffer permanent solutions to road threats.

\section{Description and geologic setting of the study area}

Ibadan-Iwo-Osogbo highway is an important well known access road, located within southwestern Nigeria. It falls in geographic coordinates of latitudes $\mathrm{N} 7^{\circ}$ $37.50^{\prime}$ to $\mathrm{N}^{\circ} 48.18^{\prime}$ and longitudes $\mathrm{E} 4^{\circ} 10^{\prime}$ to $\mathrm{E} 4^{\circ} 30^{\prime}$ 010 . The highway under study extends about $86 \mathrm{~km}$ long and trends southwest - northeast (see Figure 1). The road being an important and major access thoroughfare, links many states, towns, cities in southwestern Nigeria and also connects them to other parts of Nigeria. This is one of the factors that lead to the heavy traffic observed along this major highway. The major highway is bounded by two major states, Oyo and Osun states and characterized by linear settlements. The area is drained mainly by River Osun, River Oba, River Aro, River Orufu, River Awon, River Eyinle and their tributaries with a dendritic drainage pattern. Streams flow from a N-S direction, which is parallel or sub-parallel to the strike of the lithologic unit in the area with its tributaries forming a dense dendritic drainage pattern. Annual elevated rate of rainfall accounts for the recharge of groundwater in the area. Aquiferous zones in a typical basement complex terrain are basically from the weathered rocks and fractured basement (Olayinka and Olayiwola, 2001).

\subsection{Geology of the area}

Lithologically, the study area falls within the Precambrian Basement Complex rocks of Nigeria, which include the gneisses and migmatites with supracrustal relics of Archean (c. $2700 \mathrm{Ma}$ ) to Proterozoic (c. $2000 \mathrm{Ma}$ ) in age (Annor, 1995). Lithologic units of Nigeria which form the Basement Complex are situated in a triangular section of the basement and constitutes part of the African Crystalline Shield within the Pan African mobile belt bordered by the South of the Tuareg Shield, West African and Congo Cratons, affected by multiple occurrences of tectonic deformations and metamorphism (Oyawoye, 1972; Woakes et al., 1987). It also stretches 


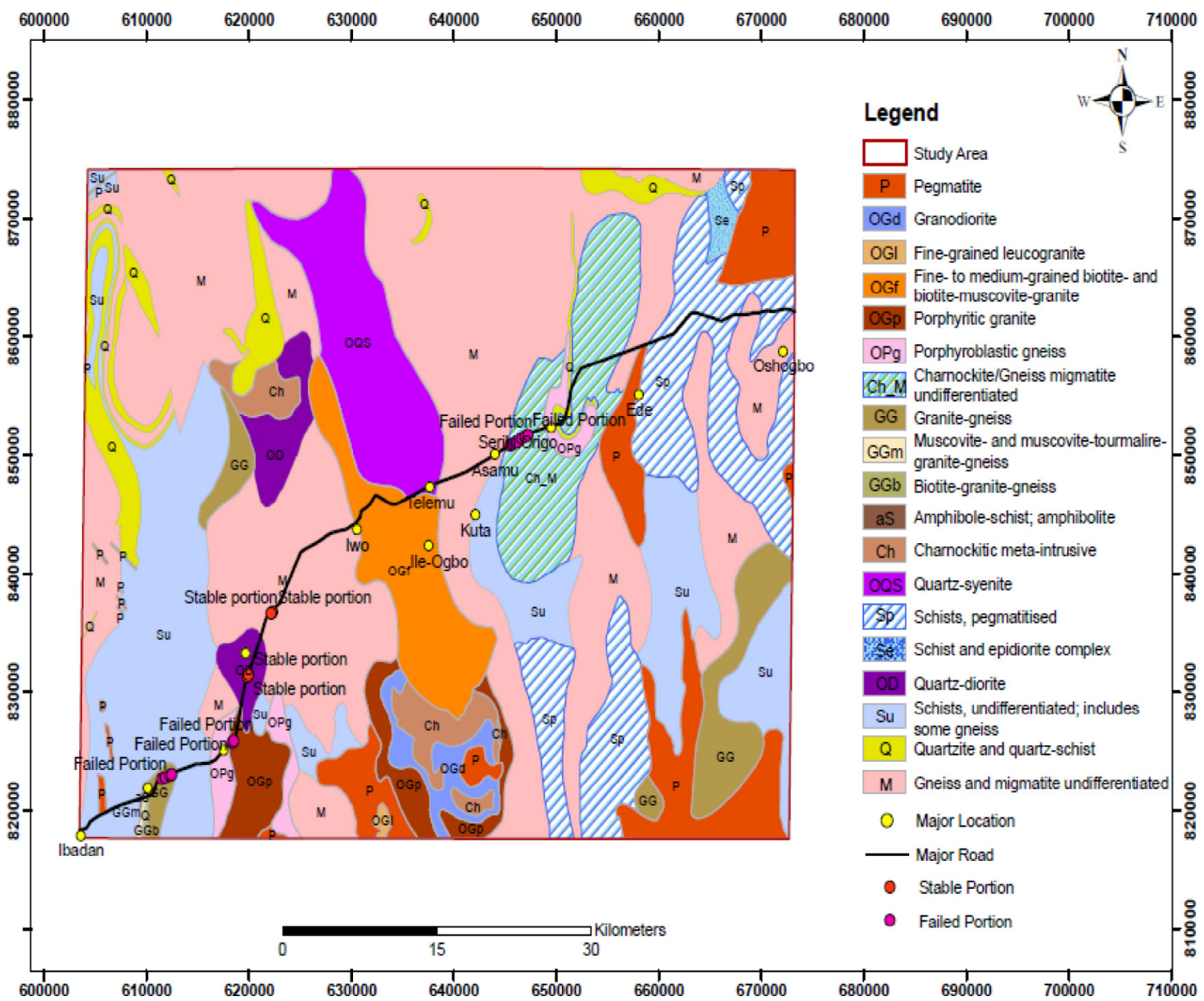

Figure 2: Geological map of the area around Ibadan-Iwo-Oshogbo Highway showing the failed and stable sections of the road (Modified after Nigeria Geological Survey Agency, 2009).

to the Dahomeyide Shield of the West African Craton. Geologic units of the area include a migmatite-gneissquartzite complex, distinguished by ultramafic rocks, felsic component comprised of pegmatite, aplite, granitic rocks and grey foliated gneiss (Rahaman, 1981). The Southwestern Nigeria migmatite-gneiss-quartzite complex has suffered major geotectonic episodes ranging from Early Proterozoic of $2000 \mathrm{Ma}$ to Pan African events of $\sim 600 \mathrm{Ma}$ (Ajibade and Fitches, 1988; Oyinloye, 2011). Major lithologic units across the highway are; charnockite, gneiss/migmatite to schist pegmatite, fine-medium grained granite, meta-intrusives, quartzosyenite and pegmatite (see Figure 2). Gneisses, migmatized in places are mostly differentiated by medium grained well classified bands of quartzo-feldspathic minerals with varying ferromagnesian minerals (Olayinka et al., 1999).

\section{Materials and methods}

This study is comprised of a comprehensive geological field mapping exercise to determine the various lithologic units in the area and to identify unstable and stable portions of the highway under study. Eighty dis- turbed and forty undisturbed soil samples were obtained at different depths of $0.5-2 \mathrm{~m}$ from twenty test pits excavated on purposively selected six failed sections (FS) and two stable sections (SS). The samples were collected orderly to ensure full coverage of the area. GPS (global positioning system) was used to take the geographic coordinates of each sampling station and its elevation above sea level. The obtained soil samples were cautiously tagged in sample bags, which were later taken to the laboratory in sealed polythene sacks to avoid loss of moisture and contamination. Natural water content of the soils was evaluated instantly at the laboratory. Thereafter, the soils were dried by air for elimination of natural moisture prior to some other analyses. After drying the soils for two weeks, in order to maintain the original sizes of individual grains, lumps present were softly ground with minimum force. Laboratory tests; natural water content, specific gravity (Gs), particle size analysis, Atterberg limits, linear shrinkage, compaction, California bearing ratio (CBR), triaxial compression, consolidation and permeability test were conducted on the soil samples in accordance with British standard test procedures for civil engineering purposes (BS 1377:1990) and ASTM Standard D1557 (2009). Each 
sample for grain size analysis was soaked in a weak Calgon solution for 24 hours to facilitate disaggregation of soil grains during wet sieving. Analysis of the grain sizes was done by a combination of wet sieving and sedimentation under gravity using Stokes law of settling velocity. The sedimentation analysis based on Stokes law was carried out by the hydrometer method. The equipment used are: balance, set of sieves, cleaning brush, sieve shaker, mixer (blender), 152H hydrometer, sedimentation cylinder, control cylinder, thermometer, beaker and timing device. The Atterberg limits are based on the moisture content of the soil. The Atterberg limits which consist of liquid limit (LL), plastic limit (PL) and plasticity index (PI) were conducted on the prepared soil samples in accordance to ASTM D 4318 (2017). Liquid limit values were determined using the Casagrande method. The equipment used was a liquid limit device, a porcelain (evaporating) dish, a flat grooving tool with gauge, moisture cans, a balance, a glass plate, a spatula, a wash bottle filled with distilled water and a drying oven set at $105^{\circ} \mathrm{C}$. About $250 \mathrm{~g}$ of a soil sample from the thoroughly mixed portion of the soil passing through $0.425 \mathrm{~mm}$ was placed in a porcelain dish and mixed with 15 to $20 \mathrm{ml}$ distilled water by alternately and repeatedly stirring, kneading and chopping with a spatula. Further water increments of 1 to $3 \mathrm{ml}$ were added and the process repeated until sufficient water had been thoroughly mixed with the soil. A portion of the mix was pressed into the cup using a spatula and carefully spread into position while avoiding the entrapment of air bubbles. The liquid limit was taken as the moisture content corresponding to 25 blows. Similarly, for the determination of plastic limit (PL), about $20 \mathrm{~g}$ of a soil sample passing a $0.425 \mathrm{~mm}$ sieve was used for the test. The sample was thoroughly mixed with distilled water and kneaded for about 10 minutes to form a plastic ball. The ball of the soil was moulded between a few fingers and rolled between the palms of the hand, such that the warmth from the hand slowly dried it. The sample was then divided into approximately three equal parts. Each of the parts was rolled into a thread between the first finger and the thumb. The thread was then rolled between the tip of the fingers of one hand and a glass plate using steady pressure which reduced the diameter to about $3 \mathrm{~mm}$. The pressure was maintained until the thread crumbled (sheared both longitudinally and transversely). This crumbling point is the plastic limit, that is, the crumbled soil was then put in the moisture container and the moisture content determined. The difference between the liquid and plastic limits gave the plasticity index. Linear shrinkage is an important parameter in the evaluation of soils as highway structural section materials, particularly subbase materials. The equipment used for this test includes a shrinkage mould made of brass, two palette knives, an evaporating dish, silicon grease, a gauge to measure length up to $150 \mathrm{~mm}$ within $0.5 \mathrm{~mm}$, a 0.425 $\mathrm{mm}$ sieve and a drying oven. About $150 \mathrm{~g}$ of air dried soil passing through a $0.425 \mathrm{~mm}$ sieve was used. The mould was cleaned, dried and a thin film of silicon grease was applied to the inner surface to prevent soil sticking to the mould. The soil was placed on a glass plate and mixed properly using distilled water for about 10 minutes until a homogenous paste of about the liquid limit was achieved. The length of the bar of soil was measured using a venire caliper, both top and bottom surfaces. The mean of the two lengths was taken as the dry length. While the specific gravity values of the soil samples collected were determined by using a pycnometer.

The linear shrinkage is given in Equation 1 as follows:

$$
\mathrm{LS}=\mathrm{L}_{\mathrm{i}}-\mathrm{L}_{\mathrm{d}} / \mathrm{L}_{\mathrm{i}} \times 100(\%)
$$

Where:

$$
\begin{aligned}
& L_{i} \text { - initial length of soil (mm), } \\
& L_{d} \text { - length of dry soil (mm). }
\end{aligned}
$$

The test to determine the optimum moisture content (OMC) and the maximum dry density (MDD) were conducted at the standard Proctor energy level in accordance with ASTM D 698 (2012). The apparatus used were: moulds, a manual rammer, an extruder, a balance, a drying oven, a mixing pan, a trowel, a $0.425 \mathrm{~mm}$ sieve, moisture cans, a graduated cylinder and a steel straight edge. For this test, the standard Proctor compaction mould was used, the compactive effort was derived from a rammer with a $50 \mathrm{~mm}$ diameter face, $2.5 \mathrm{~kg}$ weight and falling from a constant height of $300 \mathrm{~mm}$ onto three layers of soil, each receiving 25 blows. About $5 \mathrm{~kg}$ of a dry soil sample was weighed and mixed thoroughly with 200-300 $\mathrm{ml}$ of water. The mould was weighed and recorded as (M1), the extension collar was then connected to the mould, and soil was added to the mould so that it was half filled, the guide tube was gently placed on the soil and held vertically and then the soil was compacted by 25 blows from the rammer. A second approximately equal layer of soil was placed in the mould and compacted with another uniformly distributed 25 blows and same to a third layer. The extension collar was then removed carefully and the excess soil trimmed. The weight of the mould and the compacted soil were recorded (M2). Two representative samples (one from the top and the other from the bottom) were then taken from the compacted soil for the determination of moisture content. At least two more compactions were carried out after the peak weight of the mould and the compacted soil sample was obtained. This was done repeatedly for the soils and the maximum dry density (MDD) and the optimum moisture content (OMC) of the soils were determined. The California bearing ratio (CBR) is an important test used in estimating the bearing capacity of highway subbase and subgrade. It is simply the ratio of the load that causes a penetration of $2.5 \mathrm{~mm}$ or $5.0 \mathrm{~mm}$ material to a standard load that causes similar penetra- 
tion on a standard California sample, notably $13.43 \mathrm{kN}$ and $20.14 \mathrm{kN}$ respectively.

The CBR is given in Equation 2 as follows:

$\mathrm{CBR}=\frac{\text { Load that caused a penetration of } 2.5 / 5.0 \mathrm{~mm} \times 100 \%}{13.43 / 20.14(\mathrm{kN})}$

Where:

CBR - California bearing ratio (\%)

The apparatus used were: the CBR machine, a mould, a measuring cylinder, a rammer, a spatula and a weighing balance. California bearing ratio (CBR) was conducted on unsoaked and soaked samples at their MDD and $\mathrm{OMC}$ in accordance with the guidelines stated in ASTM D 1883 (2016). The CBR test was carried out with a mould of capacity $945 \times 10^{-6} \mathrm{~m}^{3}$ at optimum moisture content and 96 hours of soaking period which simulated the prolonged inundation and submergence encountered during the peak of rainy season. About $6 \mathrm{~kg}$ materials were prepared at the OMC and compacted using a $4.5 \mathrm{~kg}$ mechanical rammer. The specimens were compacted in the three layers under 55 blows of rammer for each. The apparatus used consisted of a motor driven compression machine with a constant penetration rate of $1 \mathrm{~mm} / \mathrm{min}$. A loading with a range of $0-10 \mathrm{kN}$ was employed for this test. A standard CBR mould, fitting and tools were used. The compacted soil in the mould was then placed under the machine plunger that operates hydraulically. The samples were loaded into the mould in three layers and each layer subjected to 55 blows from a $2.5 \mathrm{~kg}$ hammer dropping from a fixed height of $300 \mathrm{~mm}$. The load measuring device was connected to the compression machine. The plunger was seated on top of the specimen in such a manner that it can move freely from the surcharge weight. The measuring device was adjusted to read zero. The machine was then switched on to start loading. The machine has a calibrated proving ring and strain gauge from which the deformation was read. The pressure was applied and the plunger pressed the soil. Readings were taken at every $0.25 \mathrm{~mm}$ penetration for top and bottom, after $7.5 \mathrm{~mm}$ penetration the machine was stopped. In the triaxial compression test, three identical samples of soil are subjected to uniformly distribute fluid pressure around the cylindrical surface. The sample is sealed in a watertight rubber membrane. Then axial load is applied to the soil sample until it fails. In the triaxial apparatus, cylindrical specimens are subjected to constant radial stresses generated by fluid pressure and an increasing axial stress generated by some loading system. In the triaxial test, each specimen usually has a different constant radial stress applied to it. The axial stress is increased until each specimen fails and the stress conditions at failure are analysed by Mohr circles, so that the apparent cohesion and angle of shearing resistance are determined. Cell pressures of 30, 60 and 90 $\mathrm{kN} / \mathrm{m}^{2}$ were applied and a maximum deviator stress was obtained at the failure point. The soil specimen was set in a triaxial chamber. The cell pressure was increased to a desired value (30 kPa for the first case and $60 \mathrm{kPa}$ in the second case and $90 \mathrm{kPa}$ for the third case). The specimen was sheared at the rate of $1 \% / \mathrm{min}$. After completion of the test, the cell pressure was released to 0 , the pressure vented and the cell was brought down by bringing the lower platen down, the cell was drained, and the porous stone and the assembly were cleaned. The mode of failure was sketched. The test was repeated for the second specimen too $(60 \mathrm{kPa}$ of cell pressure and third specimen $90 \mathrm{kPa}$ of cell pressure). The applied 30, 60 and $90 \mathrm{kPa}$ led to compressive failure of the soil. However, the peak value becomes insignificant when the cell pressure is greater than $90 \mathrm{kPa}$. The results of the triaxial compression tests for the soils are presented in the form of stress-strain curves and plots of shear stress versus normal stress. From these, the strength parameters; cohesion (c) and angle of internal friction (f) were obtained. Typical stress-strain curves for the soil samples and the Mohr circles for the soil samples at peak strength are plotted and a typical example shown in Fig. 9. A onedimensional consolidation test was carried out in accordance with the British Standard, BS (1990). The soil samples were compacted at optimum moisture content, cored into the oedometer ring and placed in the consolidometer set up. Compression readings were recorded between 10 secs and 24 hours during the loading stage for each incremental load. From the consolidation test results, the coefficient of consolidation $\left(\mathrm{c}_{\mathrm{v}}\right)$ obtained enables the rate of settlement of the full-scale structure to be calculated. The load-settlement data obtained from the full cycle of loading and unloading are used to draw a pressure-voids ratio curve from which the coefficient of volume compressibility $\left(\mathrm{m}_{\mathrm{v}}\right)$ is derived. The apparatus used are: a consolidation device (including a ring, porous stones, water reservoir, and load plate), a dial gauge, a sample trimming device, a glass plate, a metal straight edge, a clock, a moisture can, and filter paper. This apparatus used is known as the oedometer. The permeability was determined directly by attaching a stand pipe to a fixed ring consolidometer and performing the falling head permeability test. This test is performed when the consolidation of the specimen is complete under the pressure increment.

\section{Results and discussion}

Road performance mainly depends on the engineering properties of the subsoil that forms the road structure. A summary of the engineering property tests, namely natural moisture content, consistency limits, specific gravity, particle size analysis, compaction, California bearing ratio (CBR), triaxial compression, consolidation and permeability are presented in Tables 1, 2 and 3. Water or moisture content is a useful expression that enables an investigator to estimate soil mass responses. Natural moisture content of soils from failed sections of the study ranges from 4.3 to $14.4 \%$, while 
that of stable sections ranges from 4.3 to $12.1 \%$. This implies that the natural water content of the soil is moderately low at its original state, which indicates low water absorption characteristics of the soil materials. The specific gravity (Gs) of the subsoil beneath the failed sections ranges from $2.64-2.70$ and that of stable sections ranges from $2.64-2.76$ as shown in Table 1. The difference in the Gs values of the soils may be due to the difference in the mineralogical composition of the soils. The soils of failed and stable sections have percentage fines ranging from $47-59 \%$ and $32-41 \%$ respectively as in Table 1. It is observed that soils of failed portions have a large amount of fines $(>47 \%)$ and fall under group A-4 to A-7 of AASHTO rating system as fair to poor highway construction material (FMWH, 2000). This indicates the ability of the soils to contract and expand constantly during distinct rainy and dry seasons of the tropical rain forest of Nigeria, with resultant noticeable distress on the highway. Instability of the highway is as a result of contributing pressures of the swelling soils. Soils of the stable portions have percentage fines of $32-41 \%$ with an average of $38 \%$, with little clay content within group A-2-4 to A-4 of AASHTO rating system as fair to good highway construction material. Although, it is slightly greater than the threshold value but does not exceed the limit of $35 \%$ stipulated by the FMWH, 2000 for highway construction material. Soils of the failed sections, being clayey indicate poor highway construction materials. The prevalence of clay and silt in the subsoil materials of the unstable portions of the highway is a contributing factor that is responsible for the persistent failure of the highway. The liquid limit and plasticity index of soils of the unstable and stable portions range from $22-64 \%, 13-41 \%$ and $32-40 \%$, $12-18 \%$ respectively (see Table 1 ). The liquid limit (LL) of $40 \%$ and $20 \%$ plasticity index (PI) were the maximum limits recommended by the Federal Ministry of Works and Housing (2000) for road subgrade material. It can be deduced from the results that some soils of the unstable sections are not competent construction materials for pavement structures due to their poor geotechnical characteristics. The high clay content of the soils is responsible for its high plasticity index (33.1 - 49.7\%) as presented in Table 1, which is an indication of high swelling potential of the soils. The plasticity chart places the soils of the unstable sections in a medium-high plasticity region (see Figure 3), while that of stable sections were placed in the low-medium plasticity region (see Figure 4). The plots on the plasticity chart show that most of the soils are above the A-line, indicative of the inorganic composition of materials with low/medium/high plasticity. Soils which plot above the U-line have unfavourable engineering characteristics compared to those that plot below and above the A-line (see Figure 3) (Wesley, 2009). Thus, they are considered as potentially problematic soils incompetent for structural construction. Meanwhile, the plot of the soils well above A-line indicate an absence of organic content in the soils. Based on the Unified Soil Classification System (USCS), the subgrade of the highway under study is composed of inorganic clays of low/medium/high plasticity $(\mathrm{CI}-\mathrm{CH})$ and fine sands. It is obvious that the subgrade soils of the failed sections (FS) 1, 2, 4 and 6 have a high proportion of fines; such soils are capable of contracting and expanding, resulting in failure of the highway. The fines of the unstable sections (FS) 1, 2, 4 and 6 are made up of clays which have a higher plasticity index and linear shrinkage values than the fines of the stable sections. The linear shrinkage (LS) values of the soils are $>8 \%$ recommended by Madedor (1983). The soils would pose a field compaction problem because of its high linear shrinkage values. These properties and behavioural characteristics of the soils should be considered very important by the civil engineers for the construction planning of the pavement structures. The contributory factor to highway instability in this area of study is a result of the development of pressures by the swelling soils. Activity, an index property used to determine the swelling potential of clay soils, i.e. the type of clay mineral present in soil, i.e. the possibility of the soil exhibiting colloidal behaviour that relates to the mineralogical composition and geologic background of clays in the soils. The activity of clay $\left(\mathrm{A}_{\mathrm{c}}\right)$ in the soils ranges from 0.34 for soil derived from the failed section (FS 3) to 1.21 for soils derived from failed section 4 (see Table 1). Most of these values are higher than those shown by kaolinitic clays ( 0.3 to 0.5$)$ and $>1.25$ indicates the presence of active clays (Holtz and Kovacs, 1981) and the presence of expansive soils in foundation soils are responsible for the failure of engineering structures erected on such soils. Soil classification based on the activity value indicate $<0.75$ as inactive clays, $0.75-1.25$ (normal clays) and $>1.25$ as active clays (Skempton, 1953). The plot in the activity chart (see Figures 5 and 6) shows that all the soils fall within the inactive and normal clays with kaolinite and illite as the dominant clay mineral in the soils having medium-high-very high expansion characteristics. Strength is an important factor to determine the load bearing capacity of soil or its ability to resist deformation under a structural load. The compaction of soil reduces its vulnerability to differential settlement and also reduces the negative effects of water on the soil. This in turn improves the geotechnical properties and performance of the soils. The understanding of compaction properties determined in terms of maximum dry density (MDD) and optimum moisture content (OMC) of the soils plays a vital role in the stability of engineering construction works. The compaction parameters at standard proctor compaction energy are presented in Table 2 and Figures 7 and 8. The MDD of soils of unstable portions of the road range from 1532 $1916 \mathrm{~kg} / \mathrm{m}^{3}$ at the $\mathrm{OMC}$ in the range of $22.4-42.1 \%$, while the MDD from stable portions vary between 1845 and $1978 \mathrm{~kg} / \mathrm{m}^{3}$ at $18.0-19.8 \%$ (OMC) (see Table 2). 
Table 1: Index properties of the soils

\begin{tabular}{|c|c|c|c|c|c|c|c|c|c|}
\hline \multirow[b]{2}{*}{ Location } & \multirow[b]{2}{*}{$\begin{array}{l}\text { Depth } \\
\text { (m) }\end{array}$} & \multirow[b]{2}{*}{$\begin{array}{l}\text { Number } \\
\text { of pit }\end{array}$} & \multirow[b]{2}{*}{ Gs } & \multicolumn{2}{|c|}{ Grain size distribution } & \multicolumn{3}{|c|}{ Consistency Limits } & \multirow[b]{2}{*}{$\begin{array}{l}\text { Range } \\
\text { of } A_{c}\end{array}$} \\
\hline & & & & $\begin{array}{l}\text { Clay-sized } \\
\text { particles range }(\%)\end{array}$ & $\begin{array}{l}\text { Fines range } \\
(\%)\end{array}$ & $\begin{array}{l}\text { LL range } \\
(\%)\end{array}$ & $\begin{array}{l}\text { PI range } \\
(\%)\end{array}$ & $\begin{array}{l}\text { LS range } \\
(\%)\end{array}$ & \\
\hline FS 1 & $0.5-2.0$ & $1-3$ & $2.64-2.69$ & $34.1-38.9$ & $48-53$ & $32.3-49.3$ & $21.4-32.1$ & $5.7-10.3$ & $0.6-0.9$ \\
\hline FS 2 & $0.5-2.0$ & $4-6$ & $2.64-2.66$ & $36.7-41.8$ & $49-55$ & $38.1-54.2$ & $23.1-38.7$ & $7.9-12.3$ & $0.6-1.0$ \\
\hline FS 3 & $0.5-2.0$ & $7-8$ & $2.67-2.70$ & $33.1-39.2$ & $47-51$ & $22.1-49.7$ & $13.3-29.1$ & $5.0-11.1$ & $0.3-0.9$ \\
\hline FS 4 & $0.5-2.0$ & $9-11$ & $2.65-2.70$ & $34.1-43.6$ & $49-52$ & $41.3-64.0$ & $29.9-41.1$ & $11.3-13.2$ & $0.8-1.2$ \\
\hline FS 5 & $0.5-2.0$ & $12-14$ & $2.64-2.68$ & $33.7-40.4$ & $47-57$ & $34.0-48.2$ & $26.4-36.4$ & $9.8-11.1$ & $0.7-0.9$ \\
\hline FS 6 & $0.5-2.0$ & $15-16$ & $2.68-2.70$ & $37.8-49.7$ & $48-59$ & $48.6-59.3$ & $34.2-41.1$ & $10.0-11.4$ & $0.8-0.9$ \\
\hline SS 1 & $0.5-2.0$ & $17-18$ & $2.66-2.72$ & $22.8-25.5$ & $33-41$ & $34.6-40.1$ & $12.6-16.8$ & $7.9-9.3$ & $0.5-0.7$ \\
\hline SS 2 & $0.5-2.0$ & $19-20$ & $2.64-2.76$ & $17.6-25.3$ & $32-39$ & $32.4-38.5$ & 14.4-18.3 & $5.0-9.3$ & $0.6-0.8$ \\
\hline
\end{tabular}

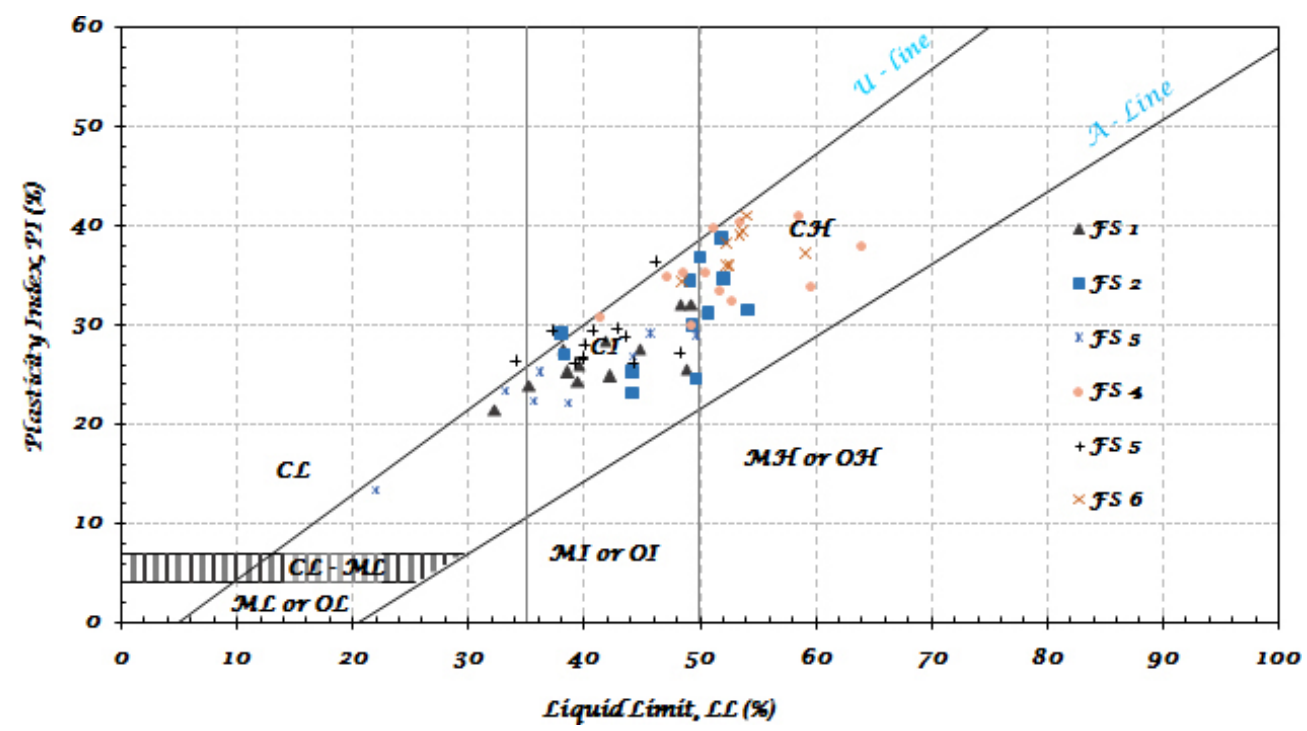

Figure 3: Plasticity chart of the soils of failed sections.

The results show low compacted density of the soils. The low range in dry density of soils of unstable portions accompanied with high moisture content is an indication of low strength in the presence of water. Increases in the failure of road pavements and other civil engineering structures are observed when the subsoil is saturated with water. This indicates that subsoil on which the road would be reconstructed must be compacted above the maximum dry density and below the optimum moisture content to achieve a stable and sustainable highway. At water content less than the optimum, the effect of increased compaction is more predominant. This can be achieved by stabilizing the soil with rock flour or cement (Ademila, 2019a; Ademila, 2019b). This is to avert moisture influx into the subgrade which may be accountable for the pavement instability and total destruction of the highway, especially during peaks of rain. Soil with high MDD at low OMC is considered suitable for engineering construction works because the higher the density of a soil, the greater its load bearing capacity and the less its tendency for water absorption with resultant enhanced resistance to settlement (Ademila, 2017). The influence of the compaction effort with changing depth is that maximum dry density increases with an increase of compactive effort. The compaction of soil increases with an increase in the amount of compactive effort and the optimum water content required for compaction also decreases with an increase in compactive effort. The inconsistency of the compaction parameters (MDD and OMC) may be the result of different levels of laterization in the weathering profiles. When the soil is compacted at water content greater than optimum water content, the dry density decreases, thus, increasing compaction energies provide higher dry densities and lower optimal water contents. The unsoaked CBR values of soils from the unstable portions vary between 7 and $77 \%$, while that of soaked CBR fall in the range $3-54 \%$ (see Table 2). This implies strength reduction or a reduction in the load bearing capacity of the soils in the presence of water. The implication of the soaked CBR is that the soils are liable to volume changes when in contact with excessive moisture. Generally, low CBR values of the soils signify relatively weak soils with an inability to sustain a vehicular load. Thus, the subgrade materials are prone to erosion on exposure to rain and runoff. The FMWH (2000) recommended a minimum value of $80 \%$ 


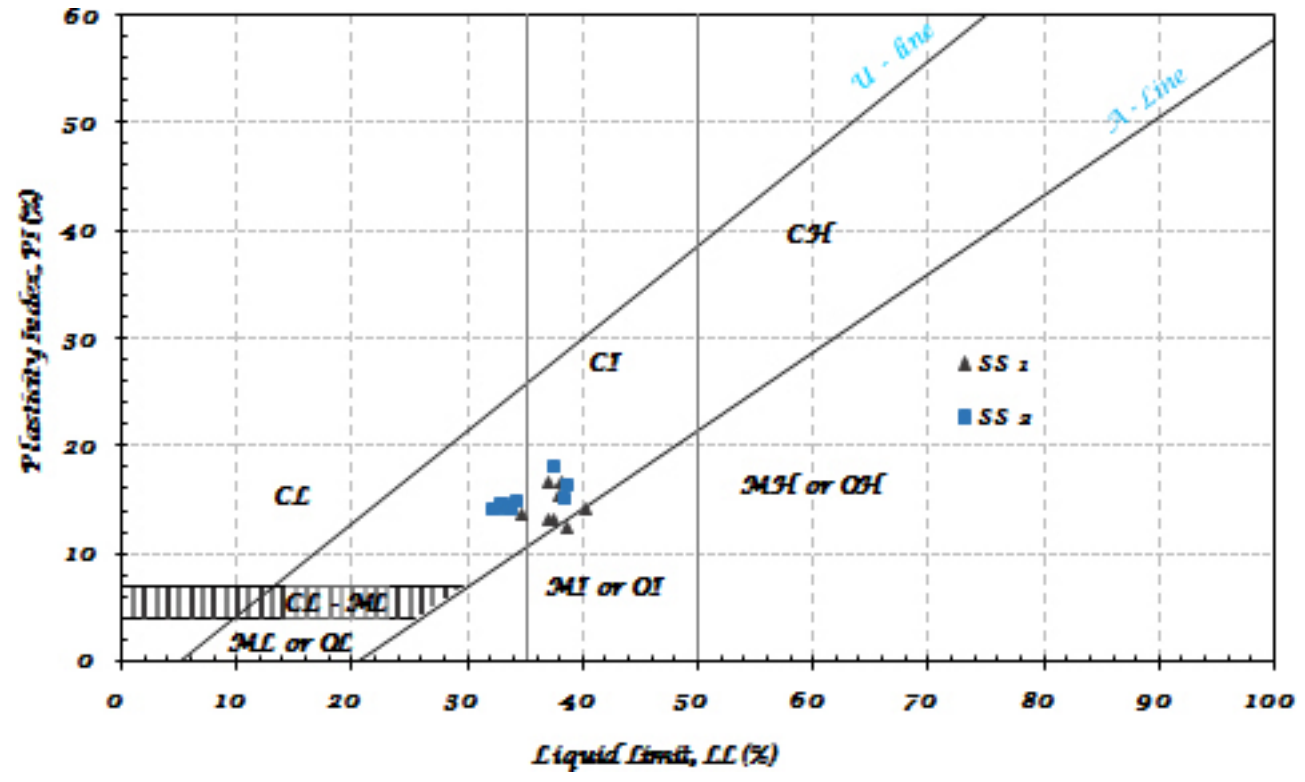

Figure 4: Plasticity chart of soils of stable sections.

Table 2: Engineering properties of the soils

\begin{tabular}{|l|l|l|l|l|l|l|}
\hline \multirow{2}{*}{ Location } & \multicolumn{2}{|l|}{ Compaction } & \multicolumn{2}{l|}{ California Bearing Ratio (CBR) } & \multicolumn{2}{l|}{ Triaxial Compression } \\
\cline { 2 - 7 } & $\begin{array}{l}\text { Range of MDD } \\
\left(\mathrm{kg} / \mathrm{m}^{3}\right)\end{array}$ & $\begin{array}{l}\text { Range of } \\
\text { OMC }(\%)\end{array}$ & $\begin{array}{l}\text { Range of unsoaked } \\
\text { CBR }(\%)\end{array}$ & $\begin{array}{l}\text { Range of soaked } \\
\text { CBR }(\%)\end{array}$ & $\begin{array}{l}\text { Cohesion } \\
\left(\mathrm{kN} / \mathrm{m}^{2}\right)\end{array}$ & $\begin{array}{l}\text { Angle of Internal } \\
\text { Friction }\left({ }^{\circ}\right)\end{array}$ \\
\hline FS 1 & $1734-1906$ & $22-32$ & $22-36$ & $16-26$ & $77-100$ & $26-33$ \\
\hline FS 2 & $1742-1856$ & $28-39$ & $23-36$ & $16-26$ & $73-98$ & $26-33$ \\
\hline FS 3 & $1896-1916$ & $22-28$ & $72-77$ & $48-54$ & $78-88$ & $31-33$ \\
\hline FS 4 & $1695-1765$ & $26-31$ & $17-19$ & $5-6$ & $98-108$ & $18-22$ \\
\hline FS 5 & $1584-1751$ & $34-42$ & $34-42$ & $23-30$ & $79-94$ & $28-30$ \\
\hline FS 6 & $1532-1586$ & $27-31$ & $7-10$ & 3 & $118-127$ & $13-16$ \\
\hline SS 1 & $1871-1949$ & $19-20$ & $13-15$ & $5-6$ & $91-96$ & $22-24$ \\
\hline SS 2 & $1845-1978$ & $18-19$ & $28-31$ & $18-20$ & $90-97$ & $23-27$ \\
\hline
\end{tabular}

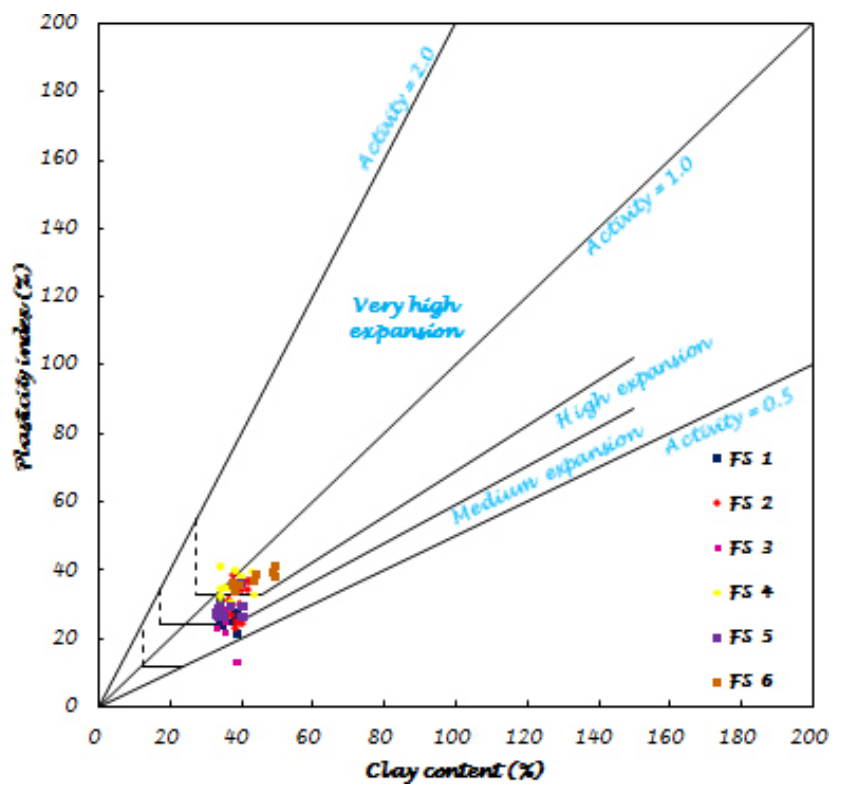

Figure 5: Activity chart of the soils of failed sections.

(unsoaked CBR) for highway subgrade. However, no analysed soils of failed and stable portions fall within

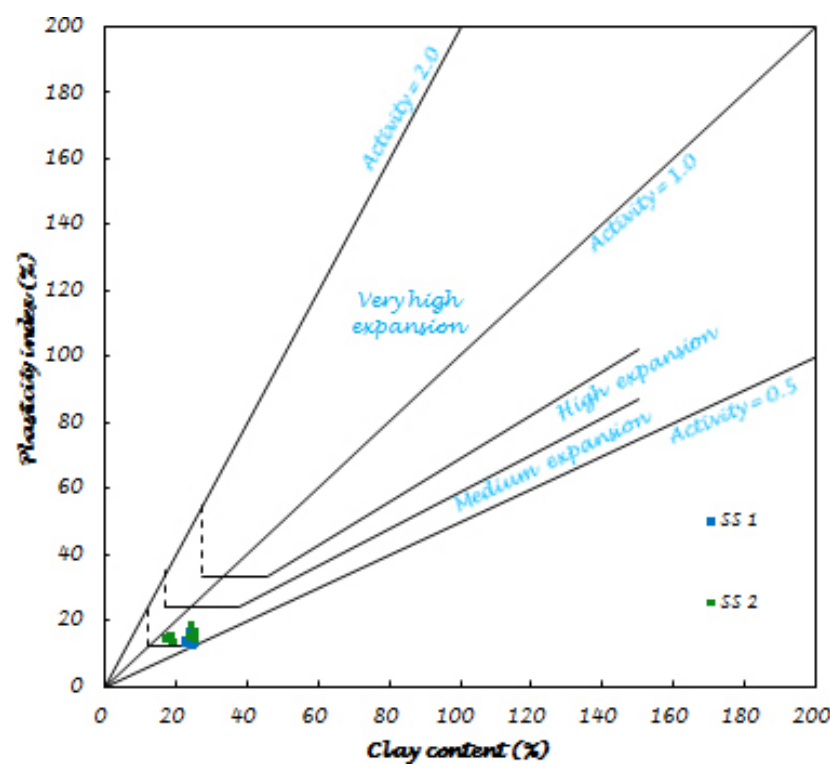

Figure 6: Activity chart of the soils of stable sections.

this requirement with the typical CBR curves shown in Figure 9. A decrease in values of soaked CBR in com- 


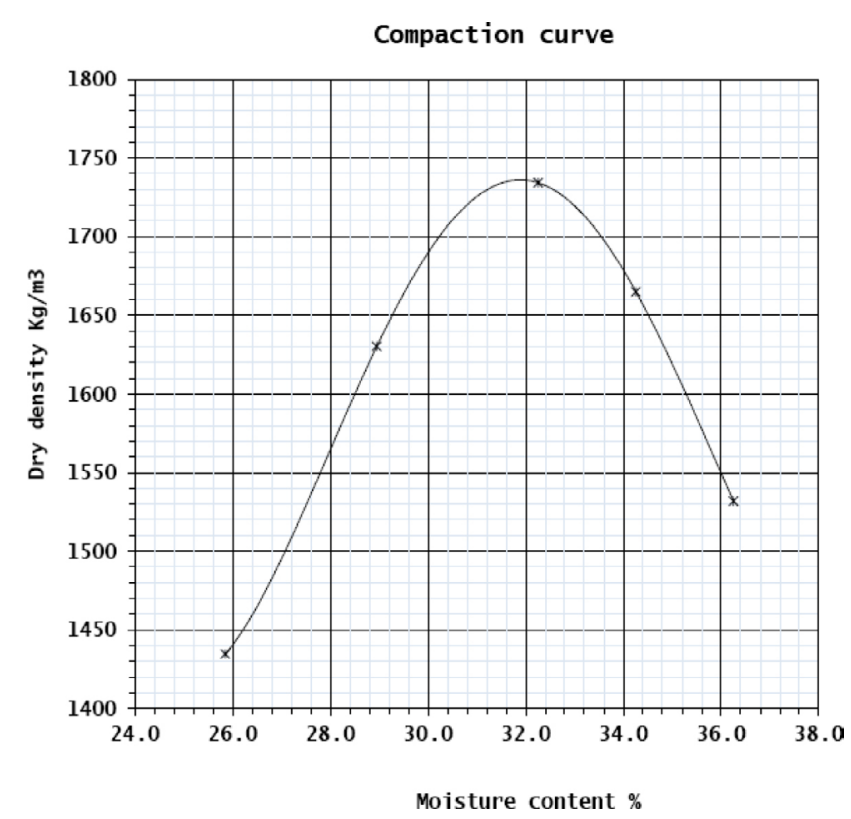

Figure 7: Compaction curve of soil of failed section 1 (FS 1/P1).

Compaction curve

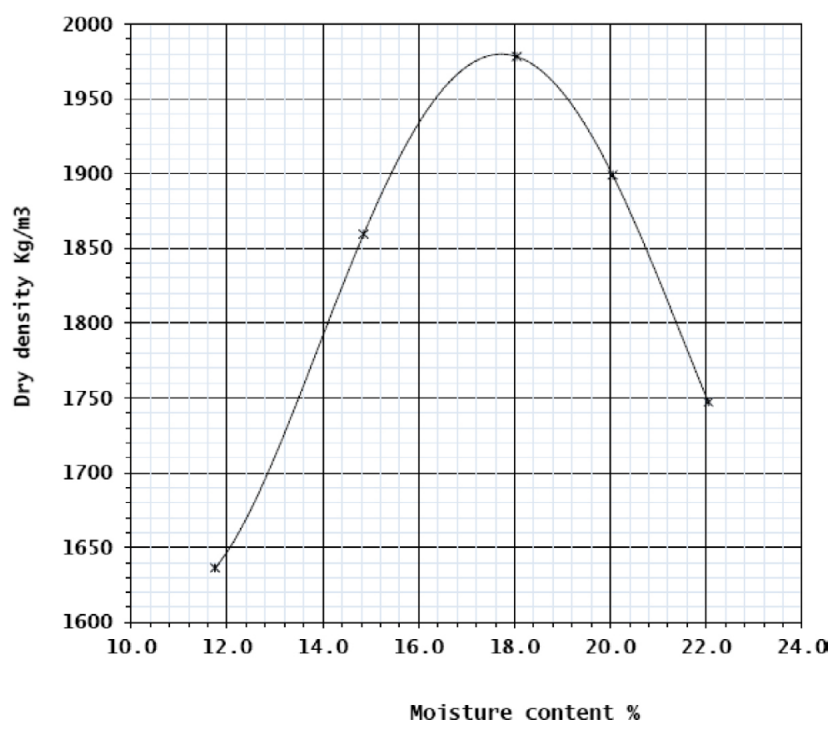

Figure 8: Compaction curve of soil of stable section 2 $\left(\mathrm{SS}_{2} / \mathrm{P}_{1}\right)$.

parison with the unsoaked CBR suggest a loss in strength with wetness. The cohesion ranges from $72.6 \mathrm{kN} / \mathrm{m}^{2}-$ $127.0 \mathrm{kN} / \mathrm{m}^{2}$ for soils of failed sections and $90.4 \mathrm{kN} / \mathrm{m}^{2}$ $-96.5 \mathrm{kN} / \mathrm{m}^{2}$ for soils of stable sections. The angle of friction ranges from $12.7^{\circ}-33.3^{\circ}$ for soil of the failed sections and $22.1^{\circ}-27.3^{\circ}$ for soil of stable sections with the triaxial curves presented in Figures 10 and 11. Generally, the values of cohesion show moderate to good shearing strength of the soils with moderately low values of angle of friction. The coefficient of volume compressibility, $\mathrm{Mv}$ in the range $0.1-0.5 \mathrm{kN} / \mathrm{m}^{2}$ (see Table 3) indicates the possibility of differential settlement to structures constructed on the failed sections soil, thus, unsuitable for road construction with its potential engi-

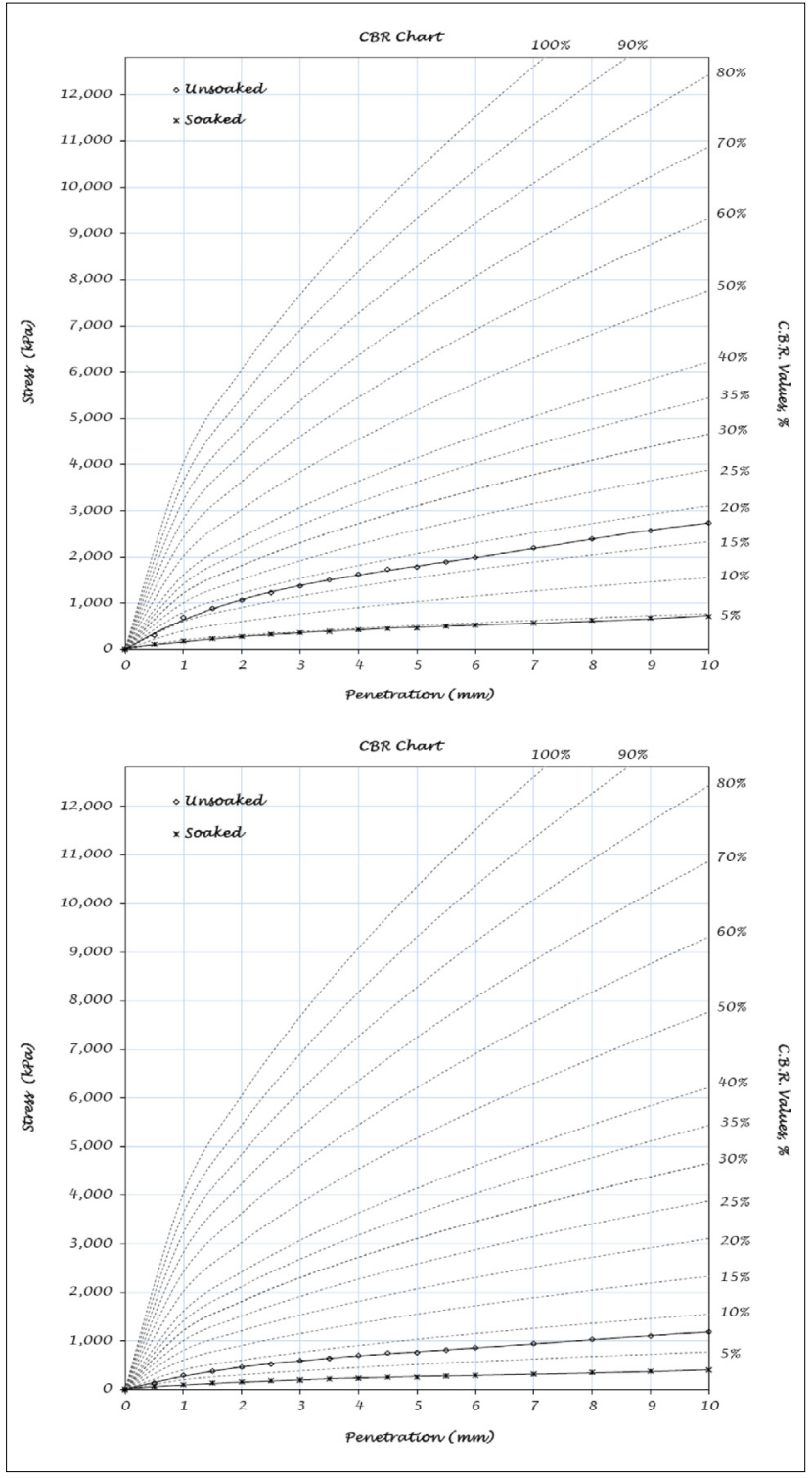

Figure 9: Typical CBR curves of the soils of failed sections (FS $4 / \mathrm{P}_{1}$ and $\mathrm{FS} 6 / \mathrm{P}_{2}$ )

neering threats, while the coefficient of consolidation, $\mathrm{Cv}$ of the soils of failed and stable sections are $0.01-$ $0.30 \mathrm{~m}^{2} /$ year (see Table 3) with the representative curves shown in Figure 12. Permeability is an important geotechnical parameter that governs the flow of water around construction works. The subsoil of the unstable portions is impervious due to their relatively low coefficients of permeability in the range $2.86 \times 10^{-7} \mathrm{~cm} / \mathrm{s}$ $2.70 \times 10^{-5} \mathrm{~cm} / \mathrm{s}$, indicating high saturation in the region. The coefficients of permeability values indicating fairly permeable subsoil materials of the stable portions (1.71 $\left.\times 10^{-6} \mathrm{~cm} / \mathrm{s}-1.08 \times 10^{-4} \mathrm{~cm} / \mathrm{s}\right)($ see Table 3). A good drainage network should be embraced for the free flow of water/surface runoff throughout the seasons. This would also prevent the wearing away of the pavement structures and weakening of the subsoil in the area due to erosion. Thus, highway construction planning should include a drainage network on both sides of the highway 


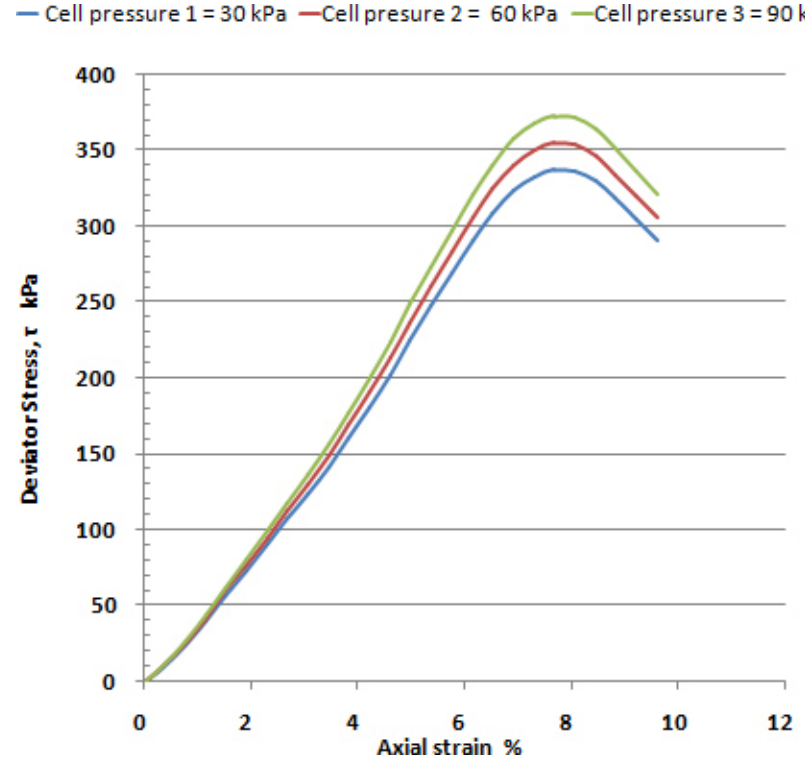

Figure 10: Typical stress-strain curves of the soil of a failed section $(\mathrm{FS} \mathrm{6/P4)}$

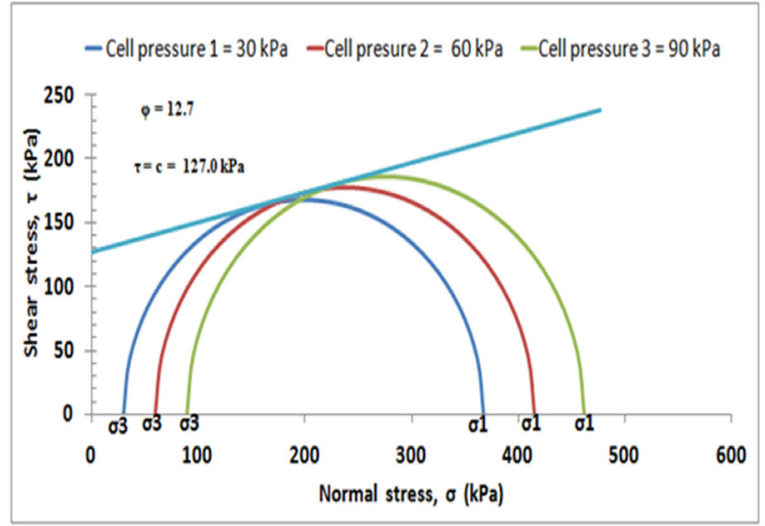

\begin{tabular}{|c|c|c|c|}
\hline Cell Pressure $O_{y y}(K P a)$ & 30 & 60 & 90 \\
\hline Maximum Deviator Stress $\left(0_{1} \cdot \sigma_{3}\right),(\mathrm{KPa})$ & 337.0 & 355.0 & 372.0 \\
\hline Cohesion (KPa) & \multicolumn{3}{|c|}{127.0} \\
\hline Angle of Friction (") & \multicolumn{3}{|c|}{12.7} \\
\hline
\end{tabular}

Figure 11: Typical Mohr circles of stress of the soil of a failed section (FS 6/P4)

Table 3: Consolidation and permeability of the soils

\begin{tabular}{|c|c|c|c|}
\hline \multirow[b]{2}{*}{ Location } & \multicolumn{2}{|c|}{ Consolidation } & \multirow[b]{2}{*}{$\begin{array}{l}\text { Permeability, } \\
\text { K }(\mathrm{cm} / \mathrm{s})\end{array}$} \\
\hline & $\begin{array}{c}\text { Coefficient of volume } \\
\text { compressibility, } \mathrm{Mv}\left(\mathrm{kN} / \mathrm{m}^{2}\right)\end{array}$ & $\begin{array}{l}\text { Coefficient of consolidation, } \\
\mathrm{Cv}\left(\mathrm{m}^{2} / \text { year }\right)\end{array}$ & \\
\hline FS 1 & $0.20-0.34$ & $0.01-0.02$ & $1.83 \times 10^{-6}-1.08 \times 10^{-5}$ \\
\hline FS 2 & $0.15-0.32$ & $0.01-0.02$ & $2.29 \times 10^{-6}-2.70 \times 10^{-5}$ \\
\hline FS 3 & $0.11-0.12$ & $0.02-0.30$ & $1.96 \times 10^{-6}-2.16 \times 10^{-6}$ \\
\hline FS 4 & $0.32-0.35$ & 0.01 & $2.00 \times 10^{-6}-4.69 \times 10^{-6}$ \\
\hline FS 5 & $0.16-0.26$ & $0.01-0.02$ & $4.49 \times 10^{-6}-2.16 \times 10^{-5}$ \\
\hline FS 6 & $0.45-0.50$ & 0.01 & $2.86 \times 10^{-7}-4.09 \times 10^{-7}$ \\
\hline SS 1 & $0.33-0.34$ & 0.01 & $5.39 \times 10^{-5}-1.08 \times 10^{-4}$ \\
\hline SS 2 & $0.26-0.33$ & 0.01 & $1.71 \times 10^{-6}-2.70 \times 10^{-6}$ \\
\hline
\end{tabular}
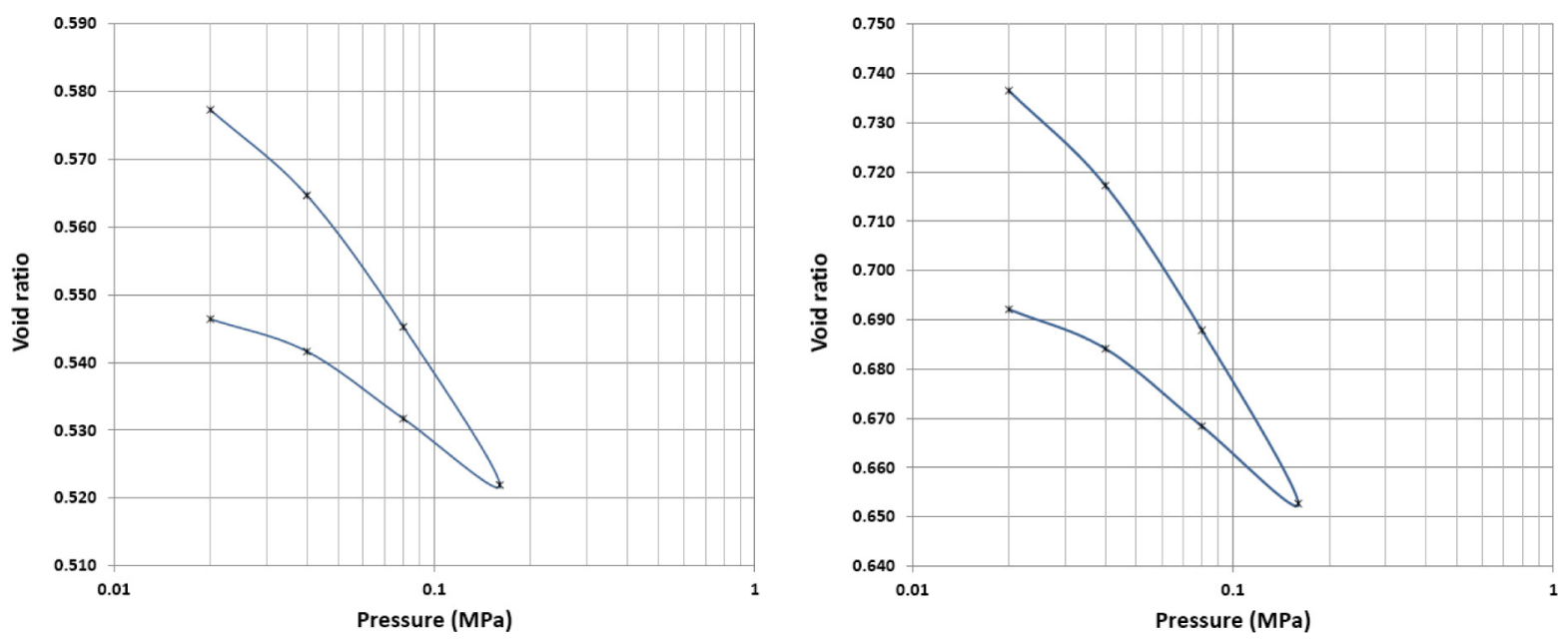

Figure 12: Representative pressure-voids ratio curves of the soil samples (FS 4/P2 and FS 6/P2).

and a description of weather conditions, because high temperatures have an adverse effect on the structural properties of bituminous materials, and thereby influence distress on flexible highways. This investigation has provided reliable information that would serve as a valuable tool and reference guide for the reconstruction of failed roads and construction of sustainable civil engineering works. Thus, documentation of the findings is 
recommended for sustainable infrastructural development.

\section{Conclusions}

Subsoil evaluation within the study area for highway construction provided information on the competence of the subsoil. This study has emphasized the importance of engineering geological investiagation towards a sustainable highway construction. The dominance of fines and medium to high plasticity, a possible indication of medium-high compressibility of the soils are contributing factors to the instability of the highway. Soils of the unstable sections lie within A-4 to A-7 of AASHTO rating system as fair to poor subgrade material for highway. Soils of FS (CI - CH) exhibit high shrinkage, high compressibility and expansion, poor compaction, low strength/stability properties and poor drainage to impervious which are the main reasons for the instability of the highway under study. Clayey poor subgrade, subbase and poor compaction during construction account for the failures of the highway pavements in the area. The coefficient of compressibility has also resulted in differential settlement of structures constructed on soils of FS. Daily activities of heavy equipment like trailers plying the road have caused the failures to manifest. The subsoil was found unsuitable as a highway material in its original state. It is recommended that the design and construction of roads and other civil engineering structures should not be concluded without proper investigation of the geologic condition and geotechnical characteristics of the subsoil which forms the foundation of these structures. Also, there should be proper documentation of the geotechnical investigation when carried out. Poor subgrade and subbase materials should be removed and replaced with appropriate fill materials that should be properly compacted or there should be modification of the subsoil to facilitate stable structures. It is further recommended that an adequate drainage network should be provided on both sides of the road to allow for the flow of water. Subsoil investigation would however be necessary to determine the suitability of subsurface materials for a stable and sustainable highway pavement.

\section{References}

Ademila, O. (2017): Engineering evaluation of lateritic soils of failed highway sections in Southwestern Nigeria. Geosciences Research, 2, 3, 210-218. Doi.org/10.22606 / gr.2017.22006.

Ademila, O. (2017): Engineering geophysical investigation of some unstable sections of Ibadan-Iwo-Osogbo Highway, Southwestern Nigeria (Unpublished PhD Thesis) University of Ibadan, Ibadan, Nigeria.

Ademila, O. (2018): Geotechnical influence of underlying soils to pavement failure in Southwestern part of Nigeria. Malaysian Journal of Sustainable Environment, 4, 2, 19-36.
Ademila, O. (2019a): Geotechnical properties and effects of palm kernel shell ash and cement on residual soils in pavement construction along Owo-Ikare Road, Southwestern Nigeria. The Pacific Journal of Science and Technology, $20,1,365-381$.

Ademila, O. (2019b): Evaluation of structural stability by characterization of lateritic soils with rock flour along Ibadan-Iwo-Osogbo Highway, Southwestern Nigeria. Conference Series 1299012072: Journal of Physics, 1-20.

Adeyemi, G.O. and Oyeyemi, F. (2000): Geotechnical basis for failure of sections of the Lagos-Ibadan Expressway, Southwestern Nigeria. Bulletin of Engineering Geology and Environment, 59, 1, 39-45.

Ajibade, A.C. and Fitches, W.R. (1988): The Nigerian Precambrian and the Pan -African Orogeny. Precambrian Geology of Nigeria, 53p.

American Association of State Highway and Transportation Officials (AASHTO) (2007): Standard specifications for transportation materials and methods of sampling and testing, 27th edition. American Association of State Highway and Transportation Officials, Washington DC, USA.

Annor, A.E. (1995): U-Pb-Zr age for Kabba-Okene granodiorite gneiss; implication for Nigeria's basement chronology. Africa Geosciences Review, 2, 101-105.

ASTM Standard D1557, (2009): Standard test methods for laboratory compaction characteristics of soil using modified effort.

American Society for Testing and Materials (ASTM) International West Conshohocken, PA. http://dx.doi.org/10.1520/ D1557-09.

ASTM D698, (2012): Standard test method for laboratory compaction characteristics of soil using standard effort $\left(12400 \mathrm{ft}-\mathrm{ibf} / \mathrm{ft}^{3}\left(600 \mathrm{kN}-\mathrm{m} / \mathrm{m}^{3}\right)\right)$. American Society for Testing and Materials, ASTM International, West Conshohocken, PA.

ASTM D1883, (2016): Standard test method for California Bearing Ratio (CBR) of laboratory compacted soils. American Society for Testing and Materials, ASTM International, West Conshohocken, PA.

ASTM D4318, (2017): Standard test methods for liquid limit, plastic limit and plasticity index of soils. American Society for Testing and Materials, ASTM International, West Conshohocken, PA.

British Standard (BS) 1377 (1990): Methods of testing soils for civil engineering purposes. British Standards Institution, London.

Federal Ministry of Works and Housing (FMWH) (2000): General specification for roads and bridges, 2, 137-275.

Holtz, R.D. and Kovacs, W.D. (1981): An introduction to Geotechnical Engineering. Prentice Hall Inc., Engleword Cliffs, New Jersey.

Madedor, A.C. (1983): Pavement design guidelines and practice for different geological area in Nigeria. In: Ola S.A. (ed) Tropical soils of Nigeria in engineering practice. A.A. Balkema, Rotterdam, Netherland, 291-297.

Nigerian Geological Survey Agency (NGSA), (2009): Geological map of Nigeria. Map prepared by Nigerian Geological Survey Agency, 31, Shetima Mangono Crescent Utako District, Garki, Abuja. 
Olayinka, A.I., Abimbola, A.F., Isibor, R.A. and Rafiu, A.R. (1999): A geoelectrical-hydrochemical investigation of shallow groundwater occurrence in Ibadan, southwestern Nigeria. Environmental Geology, 37, 1 and 2, 31-39.

Olayinka, A.I., Oladunjoye, M.A., Osinowo, O.O. and Adeyemi, G.O. (2007): Integrated geophysical investigation to determine causes of structural failures at a factory site in Benin City, Nigeria, EAGE $69^{\text {th }}$ Conference and Exhibition, London, United Kingdom. 11-14.

Olayinka, A.I. and Olayiwola, M.A. (2001): An integrated use of geoelectrical imaging and hydrogeochemical methods in delineating limits of polluted surface and groundwater at a landfill site in Ibadan area, southwestern Nigeria. Journal of Mining and Geology, 37, 1, 53-68.

Oyawoye, M.O. (1972): The basement complex of Nigeria. In African Geology. T.F.J.Dessanvagie and Whiteman (Eds) Ibadan University Press. 67-99p.

Oyinloye, A.O. (2011): Geology and geotectonic setting of the Basement Complex rocks in Southwestern Nigeria: Impli- cations on provenance and evolution. Earth and Environmental Sciences, 98 - 117. ISBN: 978-953-307-468-9.

Rahaman, M.A. (1981): Recent advances in the study of the Basement Complex of Nigeria. [in:] The Precambrian Geology of Nigeria: (Proceedings of the First Symposium on the Precambrian Geology of Nigeria organized by the Geological Survey of Nigeria, under the auspicies of the Federal Ministry of Mines and Power, from 14th to $17^{\text {th }}$ October 1981 at Durbar Hotel, Kaduna, Geological Survey of Nigeria. 11-43.

Skempton, A.W. (1953): The colloidal activity of clays. Proceedings of the $3 \mathrm{rd}$ international conference on soil mechanics and foundation engineering, 1, 57-62.

Woakes, M., Rahaman, M. A. and Ajibade, A. C. (1987): Some metallogenetic features of the Nigerian Basement. Journal of African Earth Sciences, 6, 5, 655-664.

Wesley, L. D. (2009): Fundamentals of soil mechanics for sedimentary and residual soils. John Wiley and Sons.

\section{SAŽETAK}

\section{Geotehničko ispitivanje pucanja kolnika - uzroci i moguća rješenja za održivu konstrukciju prometnica u supsaharskoj Africi}

Kako bi se otkrili razlozi neprekidnoga lomljenja i pucanja kolnika duž ceste Ibadan-Iwo-Osogbo, napravljena su inženjerskogeološka istraživanja i nestabilnih i stabilnih odsjeka ceste. Uzeto je 80 poremećenih i 40 neporemećenih uzoraka tla s različitih dubina iz 20 testnih bušotina smještenih na 6 razlomljenih i 2 stabilna odsjeka. Načinjena je analiza konstrukcije ceste uporabom tih uzoraka i standardnih metoda. Vrijednosti granice tekuće faze (22 - 64 i 32 - $40 \%$ ), indeks plastičnosti (13- 41 i 12 - 18 \%) te postotak finoće (47 - 59 i $32-41 \%)$ uputili su na solidan do loš stupanj za razlomljene i solidan do dobar stupanj za stabilne odsjeke. Srednji do velik indeks plastičnosti i znatan udio gline u tlu na razlomljenim dijelovima pokazali su kako takvo tlo ima srednji do visok potencijal bubrenja. Glina u tim tlima imala je aktivnost 0,3 - 1,2 te je klasificirana kao neaktivna do stabilna glina. Velik iznos linearnoga skupljanja (>10 \%), mala gustoća (kompakcija) i prevladavanje sitnozrnatoga detritusa uzrokom je nestabilnosti. Izloženost velikoj vlazi uzrokovala je smanjenje čvrstoće tla. Trosna kompresija uputila je na koheziju $\left(72,6-127,0 \mathrm{kN} / \mathrm{m}^{2}\right)$ te unutarnje trenje $\left(12,7-33,3^{\circ}\right)$ pokazujući umjerenu do dobru smičnu čvrstoću takva tla. Koeficijent kompresibilnosti $\left(0,1-0,5 \mathrm{kN} / \mathrm{m}^{2}\right)$ uputio je na nepogodnost tla za gradnju prometnice, kao i koeficijent konsolidacije (o,o1 - o,o3 $\mathrm{m}^{2} / \mathrm{god}$ ). Tlo je ispod razlomljenih odsjeka nepropusno s relativno malim koeficijentom propusnosti te visokim (regionalnim) zasićenjem. Dakle, lomovi su uzrokovani apsorpcijom vode u glinovito tlo, a time i slabim geotehničkim parametrima, odnosno slabom drenažom.

\section{Ključne riječi:}

lom prometnice, geotehnički parametri, temelji prometnice, aktivnost gline, cesta Ibadan-Iwo-Osogbo

\section{Authors' contribution}

Omowumi Ademila (1) (Senior Lecturer) participated in all the work stages; geological field mapping, collection of soil samples for laboratory tests, data analyses, interpretation and presentation of the results. Abel Idowu Olayinka (2) (Professor) initialized the idea, managed the whole process, shared contributions in all phases of the research and supervised it from the beginning to the end. 